\title{
Pengembangan Robot Berkaki Enam yang dapat Mengidentifikasi Ruang pada Map Kontes Robot Pemadam Api Indonesia menggunakan Algoritma Pengenalan Karakter Ruang
}

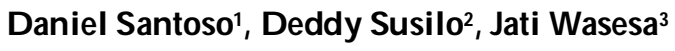 \\ Program Studi Teknik Elektro, \\ Fakultas Teknik Elektronika dan Komputer, \\ Universitas Kristen Satya Wacana, Salatiga \\ ${ }^{1}$ daniel.santoso@staff.uksw.edu, ${ }^{2}$ deddy.susilo@staff.uksw.edu, \\ 3612011018@student.uksw.edu
}

\begin{abstract}
Ringkasan
Pada sistem perlombaan KRPAI berkaki terdapat bonus nilai aturan start di dalam ruangan (arbitrary start) dengan syarat robot dapat kembali ke dalam ruang tempat awal robot start (home base). Pada perlombaan-perlombaan sebelumnya, robot pemadam api berkaki R2C belum dapat membedakan ruangan, sehingga pada tiap perlombaan belum dapat mengambil bonus arbitrary start tersebut. Sebagai indikator penanda, akan dipasangkan penampil seven - segment 1 digit untuk mengindikasikan tiap ruangan yang di kunjungi. Dengan menggunakan algoritma khusus yang dirancang untuk mengenali karakteristik tiap ruangan, robot dapat mengidentifikasi ruangan yang sedang dimasuki. Algoritma ini telah diterapkan pada robot berkaki enam yang dilengkapi sensor jarak ultrasonik, kompas elektronik, dan sensor foto dioda pendeteksi garis penanda pintu masuk ruangan. Pengujian telah dilakukan dengan cara menjalankan robot melewati berbagai rute sebanyak total 90 kali dengan persentasi keberhasilan identifikasi ruang yang dikunjungi sebesar $95,55 \%$.
\end{abstract}

Kata kunci: Algoritma identifikasi ruang, robot berkaki enam, sensor jarak, sensor fotodioda, kompas elektronik

\section{Pendahuluan}

Pada Kontes Robot Pemadam Api Indonesia (KRPAI) yang selalu diselenggarakan pada tiap tahun, tim Robotic Reasearch Center (R2C) Universitas Kristen Satya Wacana (UKSW) Salatiga selalu ikut serta dalam perlombaan tersebut. Namun masih terdapat beberapa kelemahan yang dimiliki oleh robot pemadam api berkaki enam milik R2C ini.

Pada tahun 2016, sistem perlombaan pada KRPAI berkaki mengalami perubahan yang awalnya hanya berupa sistem battle menjadi sistem time trial. Karena sistem perlombaan yang masih baru, robot berkaki enam ini masih belum memiliki algoritma identifikasi ruangan - ruangan yang ada dalam map. Dengan diterapkannya algoritma identifikasi ruang ini, diharapkan robot dapat memiliki strategi - strategi dalam menemukan ruangan ber-api. 
Pada sistem perlombaan juga terdapat bonus nilai aturan start di dalam ruangan (arbitrary start) dengan syarat robot dapat kembali ke dalam ruang tempat awal robot start (home base). Pada perlombaan-perlombaan sebelumnya, robot pemadam api berkaki R2C belum dapat membedakan ruangan, sehingga pada tiap perlombaan belum dapat mengambil bonus arbitrary start tersebut. Sebagai indikator penanda, akan dipasangkan penampil seven - segment untuk mengindikasikan tiap ruangan yang di kunjungi.

\section{Kajian Pustaka}

Beberapa robot dengan tujuan sejenis telah dikembangkan dengan menggunakan berbagai macam algoritma pengendali. Pada bab ini akan dibahas beberapa di antaranya sebagai bahan acuan dan perbandingan.

1. Pengembangan Algoritma Pengendali Robot Berkaki Enam untuk Kontes Robot Pemadam Api Indonesia [1]

Secara garis besar, sistem yang dibuat terdiri dari mikrokontroler, sensorsensor, perangkat keras pemadam api, dan algoritma robot. Mikrokontroler difungsikan sebagai pengendali utama dari sistem yang berguna untuk membaca data sensor, mengolah data dan kemudian memberikan perintah kepada servo controller dan pemadam api. Sensor-sensor berguna untuk membantu robot dalam bernavigasi, memulai pergerakan, mendeteksi terang dan gelap permukaan lantai, mendeteksi adanya titik api, dan mendeteksi boneka anjing. Terdapat dua macam perangkat keras pemadam api yaitu menggunakan air yang dipompa dengan sebuah motor (extinguisher) dan menggunakan kipas yang diputar oleh sebuah motor. Algoritma robot yang digunakan ada dua jenis, yaitu algoritma pertama yang merupakan algoritma yang dirancang dalam penelitian ini dan algoritma yang ke - dua merupakan penyempurnaan algoritma yang pernah dipakai tim R2C-LYNX.

Pengujian dilakukan dalam tiga sesi di mana pada tiap sesi, robot diuji sebanyak 42 kali. Dalam sebuah sesi setiap algoritma diuji sebanyak 21 kali. Persentase keberhasilan algoritma pertama pada sesi pertama $76,19 \%$, pada sesi ke - dua 80,95 \%, dan pada sesi ke - tiga 80,95\%. Persentase keberhasilan algoritma ke - dua pada sesi pertama $71,43 \%$, pada sesi ke - dua $76,19 \%$, dan pada sesi ke - tiga $71,43 \%$.

2. Kontrol Penjejak Pada Robot Pemadam Api Menggunakan Sistem Pengindera Api dan Posisi Jarak dengan Metode Fuzzy Logic [2]

Secara garis besar, sistem yang dibuat terdiri dari sensor TPA81, sensor jarak, sensor uv-tron, mikrokontroloer, dan perangakat keras pemadam api. Mikrokontroler digunakan sebagai pengendali utama dari sistem yang berguna untuk membaca data sensor, mengolah data dan kemudian menentukan serta memberikan perintah dengan algoritma yang mana yang lebih efektif dalam penyelesaian pemadaman api dalam ruangan.

Dalam sistem ini, terdapat 2 algoritma khusus untuk proses pemadaman api yang akan diaplikasikan pada lilin tanpa alas (candle location) maupun lilin dengan alas serta 1 algoritma untuk liin yang tertutup dengan dinding. Dari 2 algoritma ini dapat diketahui tingkat efektifitas dalam memadamkan api. 
Pengembangan Robot Berkaki Enam yang dapat Mengidentifikasi Ruang pada Map

Kontes Robot Pemadam Api Indonesia menggunakan Algoritma Pengenalan Karakter

Ruang

Daniel Santoso, Deddy Susilo,Jati Wasesa

3. Optimalisasi Algoritma Pergerakan dengan Menggunakan Cut Motion yang diterapkan untuk Robot Berkaki Enam pada Kontes Robot Pemadam Api Indonesia [3]

Secara garis besar, sistem yang dibuat terdiri dari mikrokontroler, sensorsensor, perangkat keras pemadam api, dan algoritma robot. Mikrokontroler difungsikan sebagai pengendali utama dari sistem yang berguna untuk membaca data sensor, mengolah data dan kemudian memberikan perintah kepada servo controller dan pemadam api. Sensor-sensor berguna untuk membantu robot dalam bernavigasi, memulai pergerakan, mendeteksi terang dan gelap permukaan lantai, mendeteksi adanya titik api, mendeteksi boneka.

Pengujian dilakukan dalam tiga sesi, dimana pada setiap sesi, algoritma pergerakan robot diuji sebanyak 30 kali. Pada sesi pertama dengan algoritma pertama diperoleh persentase keberhasilan robot dalam mengikuti dinding sebesar $40 \%$ dan $90 \%$ untuk berhenti sebelum boneka. Dengan menggunakan algoritma ke - dua diperoleh persentase keberhasilan robot dalam mengikuti dinding sebesar $80 \%$ dan $100 \%$ untuk berhenti sebelum boneka. Pada sesi kedua diperoleh persentase keberhasilan sebesar 36,67\% untuk algoritma pertama dan $100 \%$ untuk algoritma ke - dua. Pada sesi ke - tiga diperoleh persentase keberhasilan sebesar 36,67\% untuk algoritma pertama dan 96,67\% untuk algoritma ke - dua.

\section{Perancangan dan Penerapan}

Sebagaimana umumnya sebuah robot, sistemnya akan terdiri dari mekanik, perangkat keras dan perangkat lunak. Titik berat penelitian ini pada pengembangan dan evaluasi kinerja algoritma identifikasi ruang, meskipun demikian hal mekanik dan perangkat keras tetap akan dibahas secara ringkas untuk memberikan pemahaman yang lebih utuh.

\subsection{Gambaran Mekanik Robot}

Mekanik robot yang digunakan dalam penelitian ini merupakan mekanik yang sama dengan yang digunakan tim robot UKSW untuk bertanding dalam KRPAI 2015. Basisnya adalah robot berkaki enam dengan ukuran panjang $29 \mathrm{~cm}$, lebar $29 \mathrm{~cm}$, dan tinggi $25 \mathrm{~cm}$ seperti yang terlihat pada Gambar 1. 


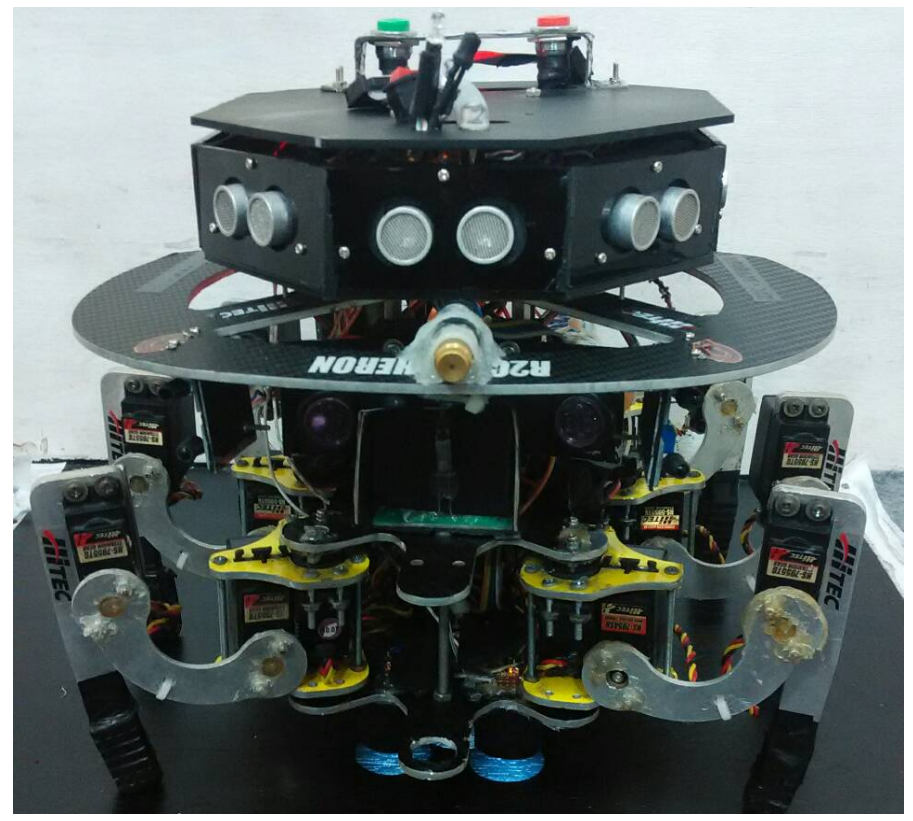

Gambar 1. Gambaran robot berkaki enam yang digunakan.

Bagian utama mekanik robot terdiri dari kaki, badan, tameng, dan kepala. Untuk bagian kaki, badan dan tameng, robot menggunakan bahan aluminium dengan ketebalan $3 \mathrm{~mm}$. Penggunaan bahan tersebut dikarenakan bahan tidak terlalu berat dan kokoh, sehingga apabila robot melakukan kontak dengan dinding, robot tidak akan mengalami kerusakan yang fatal. Sedangkan untuk bagian kepala robot menggunakan bahan plastik acrylic yang berbentuk segi delapan, bagian kepala ini digunakan sebagai wadah sensorsensor, regulator, serta mikrokontroler pengolah data dan mikrokontroler utama.

Kepala robot dibuat berbentuk segi delapan untuk meletakkan 8 buah sensor jarak ultrasonik pada setiap sisinya. Pemasangan sensor jarak dengan peletakan tersebut diperlukan agar robot dapat mengetahui kondisi sekitar dengan baik. Tameng robot berguna untuk melindungi bagian kaki terutama motor servo dan juga sensor-sensor yang ada di robot terutama sensor ultraviolet yang letak nya paling depan apabila robot menabrak dinding atau furniture.

Pada bagian tengah, terdapat sebuah mikrokontroler yang merupakan salah satu bagian dari pengendali motor servo. Disini juga terdapat 2 buah regulator tegangan untuk mencatu daya pada 18 servo. Sensor fotodioda sebanyak 7 buah diletakkan di bagian bawah. Deretan sensor ini berfungsi untuk membedakan 3 macam warna yaitu warna hitam lantai, warna putih garis pada pintu ruangan, dan warna abu-abu karpet.

\subsection{Perangkat Keras Robot}

Perangkat keras yang digunakan untuk mendukung penerapan algoritma identifikasi ruang terlihat Gambar 2. Tidak semua bagian robot dibahas dan ditunjukkan disini, hanya yang berkaitan dengan algoritma tersebut saja. 
Pengembangan Robot Berkaki Enam yang dapat Mengidentifikasi Ruang pada Map Kontes Robot Pemadam Api Indonesia menggunakan Algoritma Pengenalan Karakter

Ruang

Daniel Santoso, Deddy Susilo,Jati Wasesa

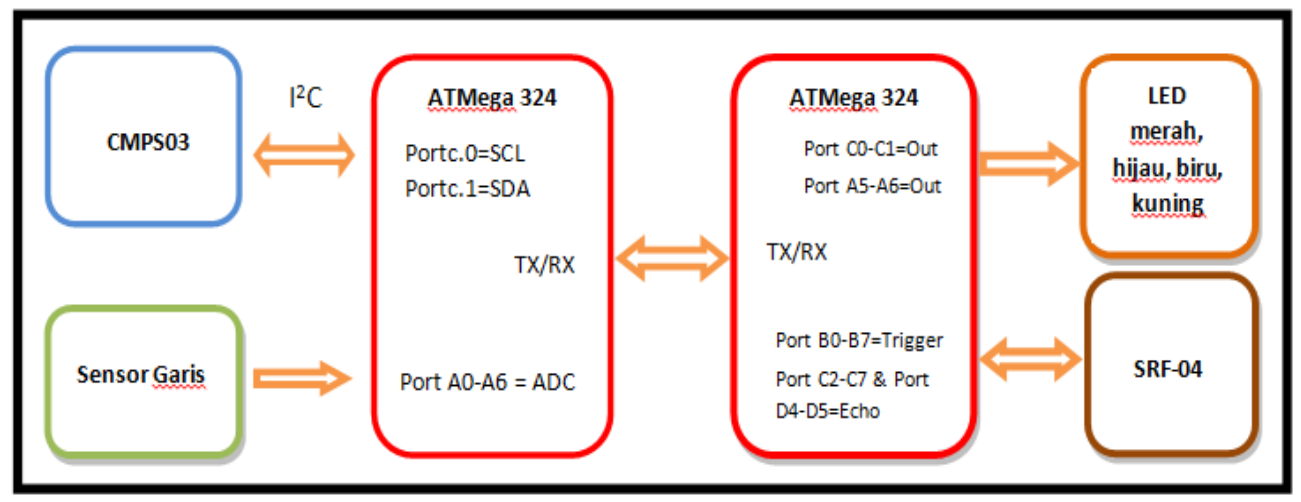

Gambar 2. Diagram blok perangkat keras sistem pendukung penerapan algoritma identifikasi ruang.

Diagram blok sistem di atas dapat di bagi menjadi beberapa bagian, yaitu: kompas elektronik, sensor garis, 2 buah mikrokontroler ATMega 324, indikator, dan sensor jarak ultrasonik.

4. Kompas elektronik

Kompas elektronik yang digunakan pada penelitian ini adalah seri CMPS03. Sensor ini memiliki 2 cara untuk diakses, yaitu melalui PWM atau melalui I2C. Orientasi robot dapat ditentukan menggunakan sensor ini.

5. Sensor fotodioda

Sensor fotodioda ini digunakan untuk mendeteksi garis putih yang ada pada tiap pintu ruangan.

6. Mikrokontroler

Untuk mengendalikan pergerakan robot digunakan 2 buah mikrokontroler Atmega324, mikrokontroler yang pertama digunakan untuk mengolah data dari kompas elektronik dan sensor garis, dan mengirimkan hasilnya ke mikrokontroler ke - dua melalui koneksi serial. Mikrokontroler yang kedua digunakan sebagai pengendali pergerakan dan pengolah algoritma identifikasi ruang.

7. Sensor jarak

Sensor jarak yang digunakan pada tugas akhir ini adalah SRF04. Sensor ultrasonik ini digunakan untuk mengetahui jarak robot dengan dinding dan juga membantu robot dalam mendeteksi halangan.

8. Indikator

Indikator yang digunakan pada tugas akhir ini adalah penampil seven - segment 1 digit yang akan menampilkan nomor ruang yang dimasuki robot.

\subsection{Perangkat Lunak Pengendali Robot dalam Mengidentifikasi Ruangan}

Diagram alir algoritma ini menjelaskan mengenai cara robot mengenali ruangan. Terdapat 2 buah diagram alir yang menjelaskan cara mengenali ruang, yaitu cara mengenali ruang pada posisi keluar ruangan (Gambar 3) dan pada posisi memasuki ruangan (Gambar 4). 


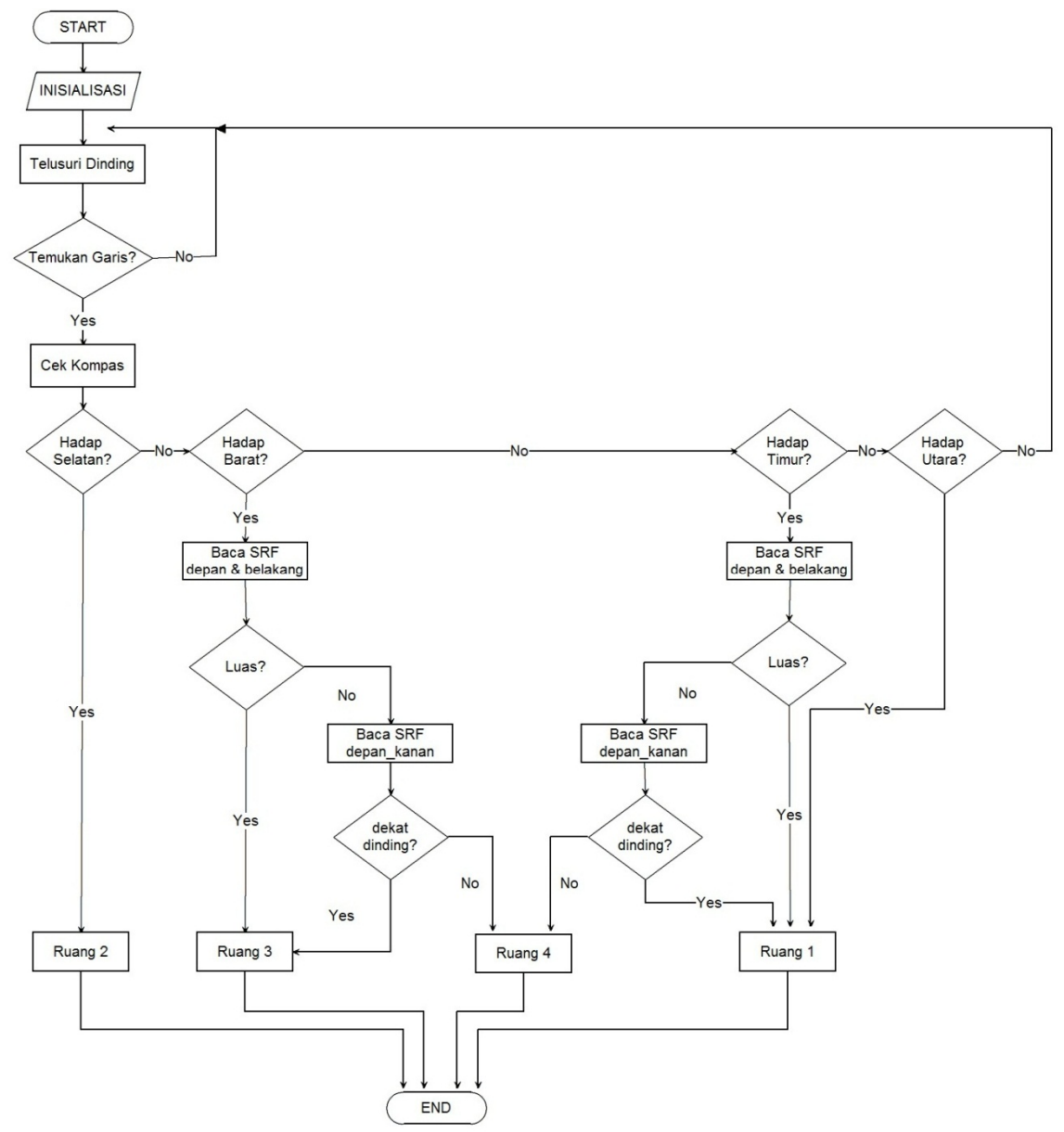

Gambar 3. Diagram alir program saat robot bergerak keluar ruangan.

Penjelasan diagram alir algoritma dengan posisi keluar ruangan adalah sebagai berikut. Saat start, robot melakukan inisialisasi, kemudian robot akan menelusuri dinding hingga menemukan garis putih yang berada pada pintu ruangan. Ketika robot menemukan garis putih, maka robot akan mengambil dan mengolah data dari kompas elektronik dengan kemungkinan - kemungkinan sebagai berikut.

1. Ketika robot mendeteksi dirinya menghadap selatan, robot akan langsung mengindikasikan bahwa dirinya berada di ruang 2 .

2. Ketika robot mendeteksi dirinya menghadap ke utara, robot akan langsung mengindikasikan bahwa dirinya berada di ruang 1 .

3. Ketika robot menghadap barat, robot akan mengambil dan mengolah data dari sensor jarak depan dan belakang. Apabila dari hasil pengolahan data sensor jarak terdeteksi bahwa ruangan luas, berarti robot berada di ruang 3, namun jika ruang terdeteksi tidak luas maka robot akan membaca data dari sensor jarak bagian depan kanan untuk mengetahui bagian depan kanan robot dekat dengan dinding atau tidak. Jika bagian depan kanan robot dekat dengan dinding berarti robot berada di ruang 3 , tetapi jika tidak dekat dengan dinding berarti robot berada di ruang 4 melalui pintu ruangan $4 \mathrm{~B}$. 
Pengembangan Robot Berkaki Enam yang dapat Mengidentifikasi Ruang pada Map Kontes Robot Pemadam Api Indonesia menggunakan Algoritma Pengenalan Karakter

Ruang

Daniel Santoso, Deddy Susilo,Jati Wasesa

4. Ketika robot menghadap timur, robot juga akan mengambil dan mengolah data dari sensor jarak depan dan belakang. Apabila dari hasil pengolahan data sensor jarak terdeteksi bahwa ruangan luas, berarti robot berada di ruang 1 melalui pintu ruangan 1A, namun jika ruang terdeteksi tidak luas maka robot juga akan membaca data dari sensor jarak bagian depan kanan untuk mengetahui bagian depan kanan robot dekat dengan dinding atau tidak. Jika bagian depan kanan robot dekat dengan dinding berarti robot berada di ruang 1 melalui pintu ruangan $1 \mathrm{~A}$, tetapi jika tidak dekat dengan dinding berarti robot berada di ruang 4 melali pintu ruangan $4 \mathrm{~A}$.

Penjelasan diagram alir algoritma dengan posisi memasuki ruangan adalah sebagai berikut. Saat start, robot melakukan inisialisasi, kemudian robot akan menelusuri dinding hingga menemukan garis putih yang berada pada pintu ruangan. Ketika robot menemukan garis putih, maka robot akan mengambil dan mengolah data dari kompas elektronik dengan kemungkinan - kemungkinan sebagai berikut.

1. Ketika robot mendeteksi dirinya menghadap utara, robot akan langsung mengindikasikan bahwa dirinya berada di ruang 2.

2. Ketika robot mendeteksi dirinya menghadap ke selatan, robot akan langsung mengindikasikan bahwa dirinya berada di ruang 1 .

3. Ketika robot menghadap timur, robot akan mengambil dan mengolah data dari sensor jarak depan dan belakang. Apabila dari hasil pengolahan data sensor jarak terdeteksi bahwa ruangan luas, berarti robot sedang mengunjungi ruang 3, namun jika ruang terdeteksi tidak luas maka robot akan membaca data dari sensor jarak bagian belakang kiri untuk mengetahui bagian belakang kiri robot dekat dengan dinding atau tidak. Jika bagian belakang kiri robot dekat dengan dinding berarti robot sedang mengunjungi ruang 3 , tetapi jika tidak dekat dengan dinding berarti robot sedang mengunjungi ruang 4 melalui pintu ruangan 4B.

4. Ketika robot menghadap barat, robot juga akan mengambil dan mengolah data dari sensor jarak depan dan belakang. Apabila dari hasil pengolahan data sensor jarak terdeteksi bahwa ruangan luas, berarti robot sedang mengunjungi ruang 1 melalui pintu ruangan 1A, namun jika ruang terdeteksi tidak luas maka robot juga akan membaca data dari sensor jarak bagian belakang kiri untuk mengetahui bagian belakang kiri robot dekat dengan dinding atau tidak. Jika bagian belakang kiri robot dekat dengan dinding berarti robot berada di ruang 1 melalui pintu ruangan $1 \mathrm{~A}$, tetapi jika tidak dekat dengan dinding berarti robot berada di ruang 4 melali pintu ruangan $4 \mathrm{~A}$. 


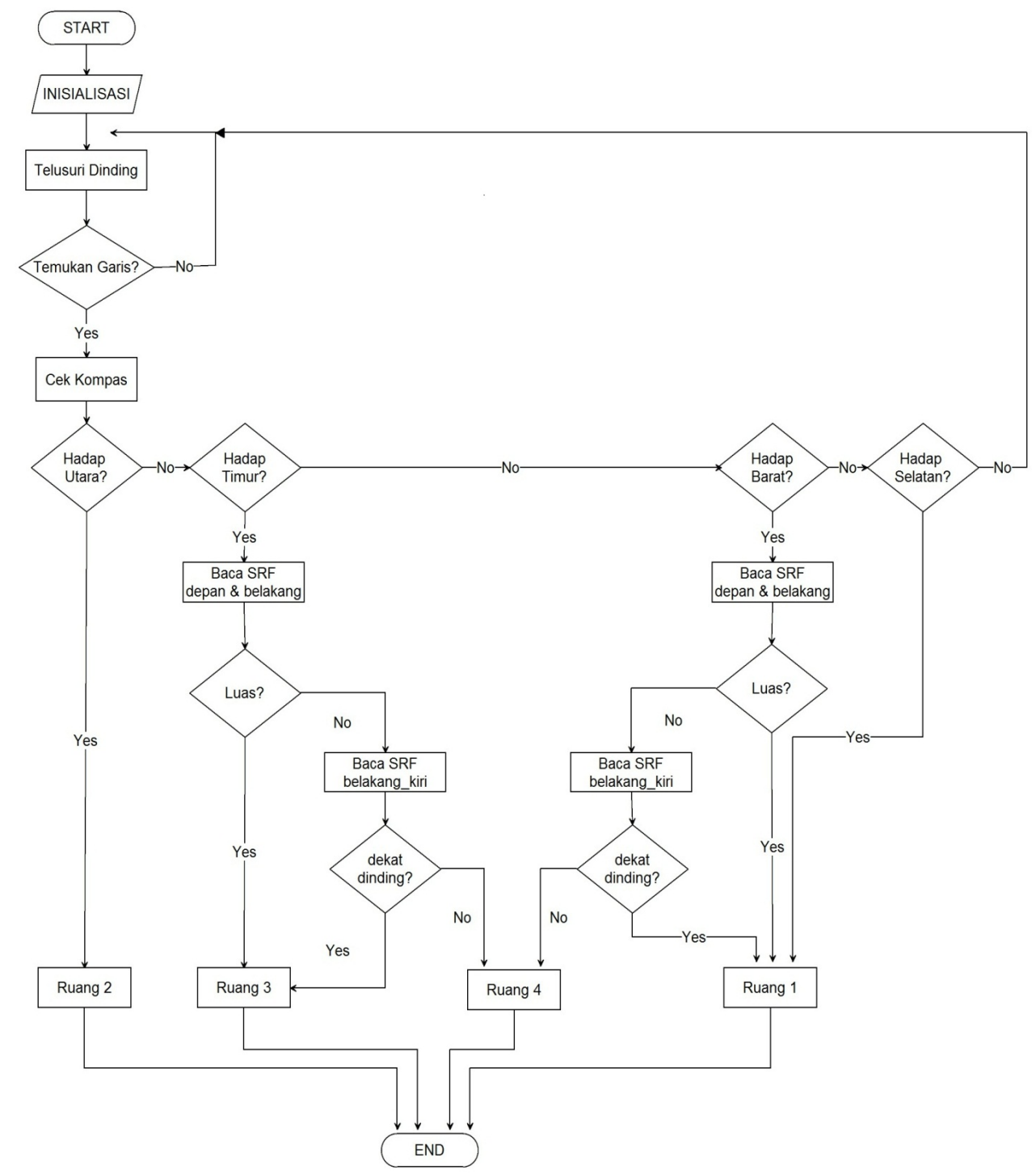

Gambar 4. Diagram alir program saat robot bergerak memasuki ruangan.

\section{Pengujian dan Pembahasan}

Pengujian dilakukan dengan 4 buah konfigurasi ruangan start, 3 buah konfigurasi peletakan dog obstacle, 2 buah konfigurasi pada pintu ruangan 1, dan 2 buah konfigurasi pintu ruangan 4. Semua konfigurasi tersebut dikombinasikan sehingga didapat total konfigurasi adalah 30 konfigurasi. Pada masing-masing konfigurasi, dilakukan pengujian sebanyak tiga kali sehingga total pengujian yang dilakukan adalah 90 kali pengujian. Gambar 5 menunjukkan konfigurasi map yang digunakan dalam pengujian. 
Pengembangan Robot Berkaki Enam yang dapat Mengidentifikasi Ruang pada Map Kontes Robot Pemadam Api Indonesia menggunakan Algoritma Pengenalan Karakter

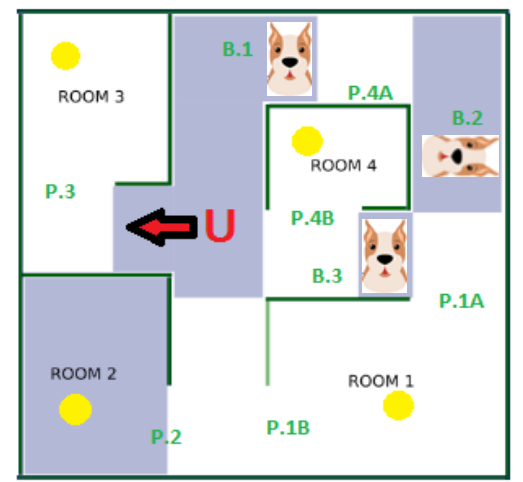

Gambar 5. Konfigurasi map beserta keterangan nomor ruang dan posisi obstacle.

\subsection{Pengujian Algoritma Identifikasi Ruangan}

Pengujian yang dilakukan adalah untuk memperlihatkan kemampuan robot dalam mengenali ruangan. Robot akan melakukan start dari dalam ruangan, kemudian ketika menemui garis putih akan mendeteksi ruangan tempat dirinya melakukan start, lalu robot akan lanjut menelusuri dinding dan ketika menemui garis putih lagi robot akan mendeteksi ruangan yang sedang dikunjungi. Pengujian pertama diringkas pada Tabel 1, pengujian ke - dua diringkas pada Tabel 2, dan pengujian ke - tiga diringkas pada Tabel 3.

\subsection{Pembahasan Hasil Pengujian}

Pada pengujian putaran pertama terjadi 2 buah kegagalan dalam mendeteksi ruang pada konfigurasi 13 dan konfigurasi 25. Kegagalan pada konfigurasi 13 diakibatkan oleh posisi robot ketika berada pada pintu ruangan tidak tegak lurus dengan pintu ruangan sehingga sensor jarak pada bagian belakang kiri robot mendeteksi adanya dinding yang dekat dengan robot, maka robot mengindikasikan bahwa ruangan tersebut adalah ruang 1. Kegagalan pada konfigurasi 25 diakibatkan karena sensor jarak pada bagian belakang kiri gagal mendeteksi dinding pada bagian belakang kiri dengan baik yang diakibatkan oleh adanya sela sambungan pada map sehingga robot mengindikasikan ruangan tersebut sebagai ruang 4. Pada putaran pertama, robot berhasil mengidentifikasi tiap ruangan dengan baik sebanyak 28 kali rute perjalanan.

Pada pengujian putaran ke - dua terjadi sebuah kegagalan dalam mengidentifikasi ruang pada konfigurasi 4. Kegagalan pada konfigurasi 4 karena sensor jarak pada bagian belakang kiri gagal mendeteksi dinding pada bagian belakang kiri dengan baik karena adanya celah sambungan pada map. Pada putaran ke - dua, robot berhasil mengidentifikasi tiap ruangan dengan baik sebanyak 29 kali rute perjalanan.

Pada pengujian sesi kedua terjadi sebuah kegagalan dalam mengidentifikasi ruang pada konfigurasi 26. Kegagalan pada konfigurasi 26 karena oleh kendurnya mur dan baut pada bagian sendi kaki setelah sekian banyak pengujian sehingga posisi robot saat berada pada pintu ruangan tidak tegak lurus kemudian menyebabkan kesalahan pembacaan sensor jarak pada bagian belakang kiri. Pada putaran ke - tiga, robot berhasil mengidentifikasi tiap ruangan dengan baik sebanyak 29 kali rute perjalanan.

Dari total pengujian sejumlah 90 kali rute perjalanan, robot dapat mengenali ruang pada 86 kali rute perjalanan. Dengan demikian persentase keberhasilan keseluruhan 
Techné Jurnal Ilmiah Elektroteknika Vol. 16 No. 1 April 2017 Hal 11 - 23

yang dicapai robot dalam mengidentifikasi ruangan pada map adalah 95,55\%. Gambar 6 menunjukkan persentase keberhasilan dari 3 putaran percobaan dalam bentuk grafik.

Tabel 1. Pengujian algoritma identifikasi ruang putaran pertama.

\begin{tabular}{|c|c|c|c|c|c|c|c|c|c|c|c|c|c|c|c|}
\hline No & Start & $\begin{array}{c}\text { Dog } \\
\text { Obstacle }\end{array}$ & Pintu & \multicolumn{6}{|c|}{ Rute } & \multicolumn{6}{|c|}{ Indikator } \\
\hline 1 & $1 \mathrm{~A}$ & B1 & A & 1 & 1 & 2 & 3 & 4 & 1 & 1 & 1 & 2 & 3 & 4 & 1 \\
\hline 2 & $1 \mathrm{~A}$ & B1 & B & 1 & 1 & 2 & 3 & 4 & 1 & 1 & 1 & 2 & 3 & 4 & 1 \\
\hline 3 & 1B & B1 & B & 1 & 2 & 3 & 4 & 1 & 1 & 1 & 1 & 2 & 3 & 4 & 1 \\
\hline 4 & 1B & B1 & $\mathrm{A}$ & 1 & 2 & 3 & 4 & 1 & 1 & 1 & 2 & 3 & 4 & 1 & 1 \\
\hline 5 & $1 \mathrm{~A}$ & B2 & $\mathrm{A}$ & 1 & 1 & 2 & 3 & 4 & 1 & 1 & 1 & 2 & 3 & 4 & 1 \\
\hline 6 & $1 \mathrm{~A}$ & B2 & B & 1 & 1 & 2 & 3 & 4 & 1 & 1 & 1 & 2 & 3 & 4 & 1 \\
\hline 7 & 1B & B2 & B & 1 & 2 & 3 & 4 & 1 & 1 & 1 & 2 & 3 & 4 & 1 & 1 \\
\hline 8 & 1B & B2 & $\mathrm{A}$ & 1 & 2 & 3 & 4 & 1 & 1 & 1 & 2 & 3 & 4 & 1 & 1 \\
\hline 9 & $1 \mathrm{~A}$ & B3 & A & 1 & 4 & 1 & 2 & 3 & 1 & 1 & 4 & 1 & 2 & 3 & 1 \\
\hline 10 & $1 \mathrm{~A}$ & B3 & B & 1 & 4 & 1 & 2 & 3 & 1 & 1 & 4 & 1 & 2 & 3 & 1 \\
\hline 11 & 1B & B3 & B & 1 & 2 & 3 & 1 & 4 & 1 & 1 & 2 & 3 & 1 & 4 & 1 \\
\hline 12 & $1 \mathrm{~B}$ & B3 & A & 1 & 2 & 3 & 1 & 4 & 1 & 1 & 2 & 3 & 1 & 4 & 1 \\
\hline 13 & 2 & B1 & A & 2 & 3 & 4 & 1 & 1 & 2 & 2 & 3 & 1 & 1 & 1 & 2 \\
\hline 14 & 2 & B1 & B & 2 & 3 & 4 & 1 & 1 & 2 & 2 & 3 & 4 & 1 & 1 & 2 \\
\hline 15 & 2 & B2 & $\mathrm{A}$ & 2 & 3 & 4 & 1 & 1 & 2 & 2 & 3 & 4 & 1 & 1 & 2 \\
\hline 16 & 2 & B2 & B & 2 & 3 & 4 & 1 & 1 & 2 & 2 & 3 & 4 & 1 & 1 & 2 \\
\hline 17 & 2 & B3 & A & 2 & 3 & 1 & 4 & 1 & 2 & 2 & 3 & 1 & 4 & 1 & 2 \\
\hline 18 & 2 & B3 & B & 2 & 3 & 1 & 4 & 1 & 2 & 2 & 3 & 1 & 4 & 1 & 2 \\
\hline 19 & 3 & B1 & A & 3 & 4 & 1 & 1 & 2 & 3 & 3 & 4 & 1 & 1 & 2 & 3 \\
\hline 20 & 3 & B1 & B & 3 & 4 & 1 & 1 & 2 & 3 & 3 & 4 & 1 & 1 & 2 & 3 \\
\hline 21 & 3 & B2 & A & 3 & 4 & 1 & 1 & 2 & 3 & 3 & 4 & 1 & 1 & 2 & 3 \\
\hline 22 & 3 & B2 & B & 3 & 4 & 1 & 1 & 2 & 3 & 3 & 4 & 1 & 1 & 2 & 3 \\
\hline 23 & 3 & B3 & $\mathrm{A}$ & 3 & 1 & 4 & 1 & 2 & 3 & 3 & 1 & 4 & 1 & 2 & 3 \\
\hline 24 & 3 & B3 & $\mathrm{B}$ & 3 & 1 & 4 & 1 & 2 & 3 & 3 & 1 & 4 & 1 & 2 & 3 \\
\hline 25 & 4 & B1 & A & 4 & 1 & 1 & 2 & 3 & 4 & 4 & 1 & 1 & 2 & 4 & 4 \\
\hline 26 & 4 & B1 & B & 4 & 1 & 1 & 2 & 3 & 4 & 4 & 1 & 1 & 2 & 3 & 4 \\
\hline 27 & 4 & B2 & $\mathrm{A}$ & 4 & 1 & 1 & 2 & 3 & 4 & 4 & 1 & 1 & 2 & 3 & 4 \\
\hline 28 & 4 & B2 & B & 4 & 1 & 1 & 2 & 3 & 4 & 4 & 1 & 1 & 2 & 3 & 4 \\
\hline 29 & 4 & B3 & $\mathrm{A}$ & 4 & 1 & 2 & 3 & 1 & 4 & 4 & 1 & 2 & 3 & 1 & 4 \\
\hline 30 & 4 & B3 & B & 4 & 1 & 2 & 3 & 1 & 4 & 4 & 1 & 2 & 3 & 1 & 4 \\
\hline
\end{tabular}


Pengembangan Robot Berkaki Enam yang dapat Mengidentifikasi Ruang pada Map Kontes Robot Pemadam Api Indonesia menggunakan Algoritma Pengenalan Karakter

Tabel 2. Pengujian algoritma identifikasi ruang putaran ke - dua.

\begin{tabular}{|c|c|c|c|c|c|c|c|c|c|c|c|c|c|c|c|}
\hline No & Start & $\begin{array}{c}\text { Dog } \\
\text { Obstacle }\end{array}$ & $\begin{array}{c}\text { Pintu } \\
4\end{array}$ & \multicolumn{6}{|c|}{ Rute } & \multicolumn{6}{|c|}{ Indikator } \\
\hline 1 & $1 \mathrm{~A}$ & B1 & A & 1 & 1 & 2 & 3 & 4 & 1 & 1 & 1 & 2 & 3 & 4 & 1 \\
\hline 2 & $1 \mathrm{~A}$ & B1 & B & 1 & 1 & 2 & 3 & 4 & 1 & 1 & 1 & 2 & 3 & 4 & 1 \\
\hline 3 & $1 \mathrm{~B}$ & B1 & B & 1 & 2 & 3 & 4 & 1 & 1 & 1 & 1 & 2 & 3 & 4 & 1 \\
\hline 4 & $1 \mathrm{~B}$ & B1 & $\mathrm{A}$ & 1 & 2 & 3 & 4 & 1 & 1 & 1 & 2 & 3 & 4 & 4 & 1 \\
\hline 5 & $1 \mathrm{~A}$ & B2 & A & 1 & 1 & 2 & 3 & 4 & 1 & 1 & 1 & 2 & 3 & 4 & 1 \\
\hline 6 & $1 \mathrm{~A}$ & B2 & B & 1 & 1 & 2 & 3 & 4 & 1 & 1 & 1 & 2 & 3 & 4 & 1 \\
\hline 7 & $1 \mathrm{~B}$ & B2 & $\mathrm{B}$ & 1 & 2 & 3 & 4 & 1 & 1 & 1 & 2 & 3 & 4 & 1 & 1 \\
\hline 8 & $1 B$ & B2 & A & 1 & 2 & 3 & 4 & 1 & 1 & 1 & 2 & 3 & 4 & 1 & 1 \\
\hline 9 & $1 \mathrm{~A}$ & B3 & $\mathrm{A}$ & 1 & 4 & 1 & 2 & 3 & 1 & 1 & 4 & 1 & 2 & 3 & 1 \\
\hline 10 & $1 \mathrm{~A}$ & B3 & B & 1 & 4 & 1 & 2 & 3 & 1 & 1 & 4 & 1 & 2 & 3 & 1 \\
\hline 11 & 1B & B3 & B & 1 & 2 & 3 & 1 & 4 & 1 & 1 & 2 & 3 & 1 & 4 & 1 \\
\hline 12 & 1B & B3 & $\mathrm{A}$ & 1 & 2 & 3 & 1 & 4 & 1 & 1 & 2 & 3 & 1 & 4 & 1 \\
\hline 13 & 2 & B1 & A & 2 & 3 & 4 & 1 & 1 & 2 & 2 & 3 & 4 & 1 & 1 & 2 \\
\hline 14 & 2 & B1 & B & 2 & 3 & 4 & 1 & 1 & 2 & 2 & 3 & 4 & 1 & 1 & 2 \\
\hline 15 & 2 & B2 & A & 2 & 3 & 4 & 1 & 1 & 2 & 2 & 3 & 4 & 1 & 1 & 2 \\
\hline 16 & 2 & B2 & B & 2 & 3 & 4 & 1 & 1 & 2 & 2 & 3 & 4 & 1 & 1 & 2 \\
\hline 17 & 2 & B3 & $\mathrm{A}$ & 2 & 3 & 1 & 4 & 1 & 2 & 2 & 3 & 1 & 4 & 1 & 2 \\
\hline 18 & 2 & B3 & B & 2 & 3 & 1 & 4 & 1 & 2 & 2 & 3 & 1 & 4 & 1 & 2 \\
\hline 19 & 3 & B1 & $\mathrm{A}$ & 3 & 4 & 1 & 1 & 2 & 3 & 3 & 4 & 1 & 1 & 2 & 3 \\
\hline 20 & 3 & B1 & B & 3 & 4 & 1 & 1 & 2 & 3 & 3 & 4 & 1 & 1 & 2 & 3 \\
\hline 21 & 3 & B2 & $\mathrm{A}$ & 3 & 4 & 1 & 1 & 2 & 3 & 3 & 4 & 1 & 1 & 2 & 3 \\
\hline 22 & 3 & B2 & B & 3 & 4 & 1 & 1 & 2 & 3 & 3 & 4 & 1 & 1 & 2 & 3 \\
\hline 23 & 3 & B3 & $\mathrm{A}$ & 3 & 1 & 4 & 1 & 2 & 3 & 3 & 1 & 4 & 1 & 2 & 3 \\
\hline 24 & 3 & B3 & B & 3 & 1 & 4 & 1 & 2 & 3 & 3 & 1 & 4 & 1 & 2 & 3 \\
\hline 25 & 4 & B1 & A & 4 & 1 & 1 & 2 & 3 & 4 & 4 & 1 & 1 & 2 & 3 & 4 \\
\hline 26 & 4 & B1 & B & 4 & 1 & 1 & 2 & 3 & 4 & 4 & 1 & 1 & 2 & 3 & 4 \\
\hline 27 & 4 & B2 & $\mathrm{A}$ & 4 & 1 & 1 & 2 & 3 & 4 & 4 & 1 & 1 & 2 & 3 & 4 \\
\hline 28 & 4 & B2 & B & 4 & 1 & 1 & 2 & 3 & 4 & 4 & 1 & 1 & 2 & 3 & 4 \\
\hline 29 & 4 & B3 & $\mathrm{A}$ & 4 & 1 & 2 & 3 & 1 & 4 & 4 & 1 & 2 & 3 & 1 & 4 \\
\hline 30 & 4 & B3 & $\mathrm{B}$ & 4 & 1 & 2 & 3 & 1 & 4 & 4 & 1 & 2 & 3 & 1 & 4 \\
\hline
\end{tabular}


Techné Jurnal Ilmiah Elektroteknika Vol. 16 No. 1 April 2017 Hal 11 - 23

Tabel 3. Pengujian algoritma identifikasi ruang putaran ke - tiga.

\begin{tabular}{|c|c|c|c|c|c|c|c|c|c|c|c|c|c|c|c|}
\hline \multirow[t]{2}{*}{ No } & \multirow{2}{*}{\begin{tabular}{|c|} 
Start \\
$1 \mathrm{~A}$ \\
\end{tabular}} & \multirow{2}{*}{$\begin{array}{c}\begin{array}{c}\text { Dog } \\
\text { Obstacle }\end{array} \\
\text { B1 }\end{array}$} & \multirow{2}{*}{$\begin{array}{c}\text { Pintu } \\
4 \\
\text { A }\end{array}$} & \multicolumn{6}{|c|}{ Rute } & \multicolumn{6}{|c|}{ Indikator } \\
\hline & & & & 1 & 1 & 2 & 3 & 4 & 1 & 1 & 1 & 2 & 3 & 4 & 1 \\
\hline 2 & $1 \mathrm{~A}$ & B1 & B & 1 & 1 & 2 & 3 & 4 & 1 & 1 & 1 & 2 & 3 & 4 & 1 \\
\hline 3 & 1B & B1 & B & 1 & 2 & 3 & 4 & 1 & 1 & 1 & 1 & 2 & 3 & 4 & 1 \\
\hline 4 & 1B & B1 & $\mathrm{A}$ & 1 & 2 & 3 & 4 & 1 & 1 & 1 & 2 & 3 & 4 & 1 & 1 \\
\hline 5 & $1 \mathrm{~A}$ & B2 & $\mathrm{A}$ & 1 & 1 & 2 & 3 & 4 & 1 & 1 & 1 & 2 & 3 & 4 & 1 \\
\hline 6 & $1 \mathrm{~A}$ & B2 & B & 1 & 1 & 2 & 3 & 4 & 1 & 1 & 1 & 2 & 3 & 4 & 1 \\
\hline 7 & 1B & B2 & B & 1 & 2 & 3 & 4 & 1 & 1 & 1 & 2 & 3 & 4 & 1 & 1 \\
\hline 8 & 1B & B2 & A & 1 & 2 & 3 & 4 & 1 & 1 & 1 & 2 & 3 & 4 & 1 & 1 \\
\hline 9 & $1 \mathrm{~A}$ & B3 & A & 1 & 4 & 1 & 2 & 3 & 1 & 1 & 4 & 1 & 2 & 3 & 1 \\
\hline 10 & $1 \mathrm{~A}$ & B3 & B & 1 & 4 & 1 & 2 & 3 & 1 & 1 & 4 & 1 & 2 & 3 & 1 \\
\hline 11 & 1B & B3 & B & 1 & 2 & 3 & 1 & 4 & 1 & 1 & 2 & 3 & 1 & 4 & 1 \\
\hline 12 & 1B & B3 & $\mathrm{A}$ & 1 & 2 & 3 & 1 & 4 & 1 & 1 & 2 & 3 & 1 & 4 & 1 \\
\hline 13 & 2 & B1 & $\mathrm{A}$ & 2 & 3 & 4 & 1 & 1 & 2 & 2 & 3 & 4 & 1 & 1 & 2 \\
\hline 14 & 2 & B1 & $\mathrm{B}$ & 2 & 3 & 4 & 1 & 1 & 2 & 2 & 3 & 4 & 1 & 1 & 2 \\
\hline 15 & 2 & B2 & A & 2 & 3 & 4 & 1 & 1 & 2 & 2 & 3 & 4 & 1 & 1 & 2 \\
\hline 16 & 2 & B2 & B & 2 & 3 & 4 & 1 & 1 & 2 & 2 & 3 & 4 & 1 & 1 & 2 \\
\hline 17 & 2 & B3 & A & 2 & 3 & 1 & 4 & 1 & 2 & 2 & 3 & 1 & 4 & 1 & 2 \\
\hline 18 & 2 & B3 & B & 2 & 3 & 1 & 4 & 1 & 2 & 2 & 3 & 1 & 4 & 1 & 2 \\
\hline 19 & 3 & B1 & A & 3 & 4 & 1 & 1 & 2 & 3 & 3 & 4 & 1 & 1 & 2 & 3 \\
\hline 20 & 3 & B1 & B & 3 & 4 & 1 & 1 & 2 & 3 & 3 & 4 & 1 & 1 & 2 & 3 \\
\hline 21 & 3 & B2 & A & 3 & 4 & 1 & 1 & 2 & 3 & 3 & 4 & 1 & 1 & 2 & 3 \\
\hline 22 & 3 & B2 & B & 3 & 4 & 1 & 1 & 2 & 3 & 3 & 4 & 1 & 1 & 2 & 3 \\
\hline 23 & 3 & B3 & $\mathrm{A}$ & 3 & 1 & 4 & 1 & 2 & 3 & 3 & 1 & 4 & 1 & 2 & 3 \\
\hline 24 & 3 & B3 & B & 3 & 1 & 4 & 1 & 2 & 3 & 3 & 1 & 4 & 1 & 2 & 3 \\
\hline 25 & 4 & B1 & $\mathrm{A}$ & 4 & 1 & 1 & 2 & 3 & 4 & 4 & 1 & 1 & 2 & 3 & 4 \\
\hline 26 & 4 & B1 & B & 4 & 1 & 1 & 2 & 3 & 4 & 4 & 4 & 1 & 2 & 4 & 4 \\
\hline 27 & 4 & B2 & A & 4 & 1 & 1 & 2 & 3 & 4 & 4 & 1 & 1 & 2 & 3 & 4 \\
\hline 28 & 4 & B2 & B & 4 & 1 & 1 & 2 & 3 & 4 & 4 & 1 & 1 & 2 & 3 & 4 \\
\hline 29 & 4 & B3 & A & 4 & 1 & 2 & 3 & 1 & 4 & 4 & 1 & 2 & 3 & 1 & 4 \\
\hline 30 & 4 & B3 & B & 4 & 1 & 2 & 3 & 1 & 4 & 4 & 1 & 2 & 3 & 1 & 4 \\
\hline
\end{tabular}

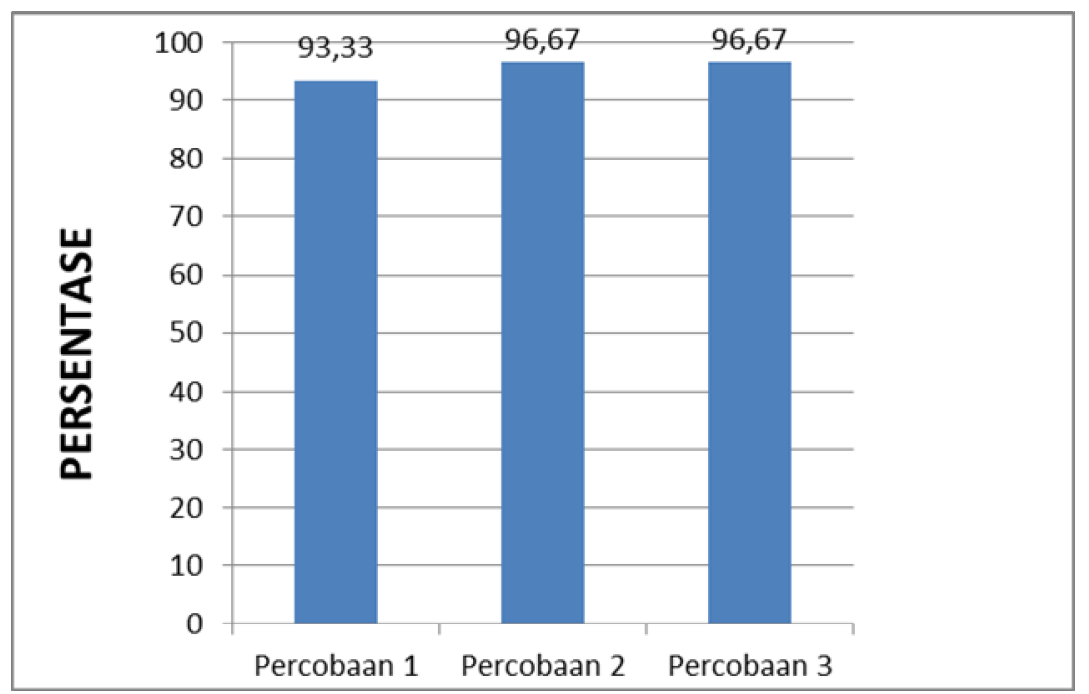

Gambar 6. Grafik persentase keberhasilan robot dalam mengidentifikasi ruangan - ruangan pada map. 
Pengembangan Robot Berkaki Enam yang dapat Mengidentifikasi Ruang pada Map Kontes Robot Pemadam Api Indonesia menggunakan Algoritma Pengenalan Karakter

Ruang

Daniel Santoso, Deddy Susilo,Jati Wasesa

\section{Kesimpulan}

Berdasarkan perancangan, penerapan dan pengujian dapat ditarik kesimpulan sebagai berikut:

1. Untuk mendukung algoritma identifikasi ruang diperlukan sensor fotodioda untuk mendeteksi garis putih penanda pintu masuk ruangan, kompas elektronik untuk menentukan orientasi robot, dan sensor jarak ultrasonik untuk mengetahui jarak robot terhadap dinding.

2. Dengan menggunakan algoritma identifikasi ruang dan sensor pendukung, robot dapat membedakan empat ruangan yang berbeda berdasar karakteristiknya.

3. Algoritma identifikasi ruang dapat digunakan dalam situasi penelusuran map sebenarnya dengan tingkat keberhasilan 95,55\% dari 90 kali percobaan dengan berbagai variasi konfigurasi map.

\section{Daftar Pustaka}

[1] D Santoso, D. Susilo, T. Handoko, "Pengembangan Algoritma Pengendali Robot Berkaki Enam untuk Kontes Robot Pemadam Api Indonesia," Jurnal Techne, vol. 13, no. 2, h. $213-221,2014$.

[2] D.B.P.Saputro, "Algoritma untuk Robot Berkaki Enam dalam Proses Menyelesaikan Pemadaman Api pada Kontes Robot Pemadam Api Indonesia", Skripsi, FTEKUKSW, Salatiga, 2015.

[3] C.D.Mahardika, "Optimalisasi Algoritma Pergerakan dengan menggunakan Cut Motion yang diterapkan untuk Robot Berkaki Enam pada Kontes Robot Pemadam Api Indonesia", Skripsi, FTEK-UKSW,Salatiga, 2016. 
Techné Jurnal Ilmiah Elektroteknika Vol. 16 No. 1 April 2017 Hal 11 - 23 